\title{
SOIL MACROFAUNA IN GREEN MANURES PRECEDING COTTON GROWING
}

\author{
MACROFAUNA DO SOLO EM ADUBOS VERDES COMO CULTURAS \\ ANTECESSORAS AO CULTIVO DO ALGODÃO
}

\author{
Elen Regina Caceres de SOUZA'ㅜㄹ Larissa Pereira Ribeiro TEODORO²; \\ Thiara de Azevedo TEZOLIN ${ }^{1}$; Alfredo Raul ABOt ${ }^{1}$; Francisco Eduardo TORRES'; \\ Ariane de Andréa PANTALEÃO ${ }^{2}$; Paulo Eduardo TEODORO ${ }^{*}$ \\ 1. Universidade Estadual de Mato Grosso do Sul - UEMS, Programa de Pós- Graduação em Agronomia , Aquidauana, MS, Brasil; 2. \\ Universidade Federal de Mato Grosso do Sul - UFMS, Agronomia e Engenharia Florestal, Chapadão do Sul, MS, Brasil.* \\ eduteodoro@hotmail.com
}

\begin{abstract}
The objective of this work was to evaluate the abundance of the soil macrofauna in four green manure species, before the cotton crop. The experimental design was a randomized block design with four treatments: Mucuna pruriens (gray mucuna), Canavalia ensiformes (pork bean), Cajanus cajan (pigeon pea) and Crotalaria juncea (crotalaria). The macrofauna was captured by means of collections with collections using pitfall traps. The data were processed through the cluster analysis to verify the similarity among green manure species as to the occurrence of soil macrofauna. The orders Orthoptera, Coleoptera L (Larval), Hymenoptera and Coleoptera (adult), respectively, had the highest local relative abundance. There was a significant effect of the cover plants on the taxonomic groups and relative density of the soil macrofauna. Green manures were more determinant in the abundance and relative density of the soil macrofauna than the region climate. Up to 60 days after sowing the cotton crop, there was a beneficial influence of the green manures on the soil macrofauna.
\end{abstract}

KEYWORDS: Canonical analysis. Cluster analysis. Gossypium hirsutum. Macrofauna density. Phylum Arthropoda.

\section{INTRODUCTION}

The use of biological, physical and chemical variables has been indicated for the evaluation of soil quality submitted to different agricultural management (SALTON et al., 2008). Among the ecological bioindicators is the soil macrofauna, composed of taxonomic groups belonging to the Phylum Annelida (earthworms) and Phylum Arthropoda (arachnids, millipedes and insects such as coleoptera in larvae or adult stages, termites and ants), among others (LAVELLE; SPAIN, 2001).

These animals are of fundamental importance for maintaining the soil quality and fertility, as they favor the redistribution of nutrients and organic matter through their biodynamic activities (LAVELLE; SPAIN, 2001). In the communities of these soil fauna organisms there is a great diversity of forms, behaviors, sizes and strategies of feeding and excavation, which can be influenced by the type of management employed, since they are sensitive to biotic and abiotic changes (AQUINO et al., 2008).

Plant residues supplied in abundance by the species used as green manure promote the adequate amount of food and serve as habitat for most invertebrate species that inhabit the soil. According to Alves et al. (2008), the highest frequencies of macrofauna are related to systems with organomineral fertilization and occurs in different cropping systems. The diverse occurrence of soil macrofauna individuals is associated with a relationship among the species, wherein the fauna diversity can also be related to other factors, such as plant density, established crops, adaptability to crop, food availability and content of soil organic matter (KLADIVKO, 2001).

Souza et al. (2017) evaluated the similarity between nine species of green manure in relation to the occurrence of epigephic macrofauna. The authors verified that Mucuna pruriens was the species with higher occurrence of epiphytic macrofauna, especially the Orthoptera and Hymenoptera. Cajanus cajan cv "fava larga" was the most common species among the individuals from Isoptera.

Among the crops used after the implantation and incorporation of vegetal remains of the species used as green manure, cotton (Gossypium hirsutum L.) has behaved as a promising crop. Cotton is a plant of great demand when it comes to soil quality, developing its maximum yield potential on fertile 
Soil macrofauna...

soils, rich in organic matter, and well structured (CORRÊIA, 1999; FREIRE, 2015). In annual crops such as cotton, owing to successive tillage, there is a risk of causing changes in soil quality. To this end, the application of measures to maintain or increase the appropriate physical, chemical and biological conditions for the plant development should be considered.

Aiming at reaching the crop potential, crop rotation and the management of crop residues by using cover crops and straw management, fertility correction and maintenance fertilization for crops are needed. The use of green fertilization in the cotton crop is of great efficiency, since it exerts benefits in the soil fauna and soil fertility by the accumulation of organic matter. At the same time, cotton growing, which is practiced in extensive farming areas, exerts a strong impact on the edaphic macrofauna and other organisms due to the high pressure of agricultural inputs (MENDES et al., 2011).

Associating the green manure with the cotton crop may become relevant from the environmental point of view, since the soil macrofauna can be considered a soil quality bioindicator. Due to its sensitivity and reaction to
SOUZA, E. R. C. et al.

changes induced by anthropic and natural activities on the soil and its vegetation cover, macrofauna provides a notion about the current soil state and changes induced by internal and external forces, i.e., biotic and abiotic forces over the time (MENEZES et al., 2009).

In view of the above, the objective of this work was to evaluate the abundance of the soil macrofauna in green manures preceding the cotton crop in the Cerrado region.

\section{MATERIAL AND METHODS}

The experiment was carried out in the experimental area of the State University of Mato Grosso do Sul (UEMS), University Unit of Aquidauana, under coordinates $20^{\circ} 27^{\prime} 11.6$ "S $55^{\circ} 40^{\prime} 22.2^{\prime \prime} \mathrm{W}$ and altitude of $170 \mathrm{~m}$. The climate, according to the Köppen climate classification, is Aw (Tropical Warm-Wet), with rainy summer and dry winter, average annual rainfall of $1,250 \mathrm{~mm}$ and an average temperature of $26^{\circ} \mathrm{C}$ (Figure 1). The region is composed of native vegetation, large pasture areas (cultivated grasses) and small domestic orchards.

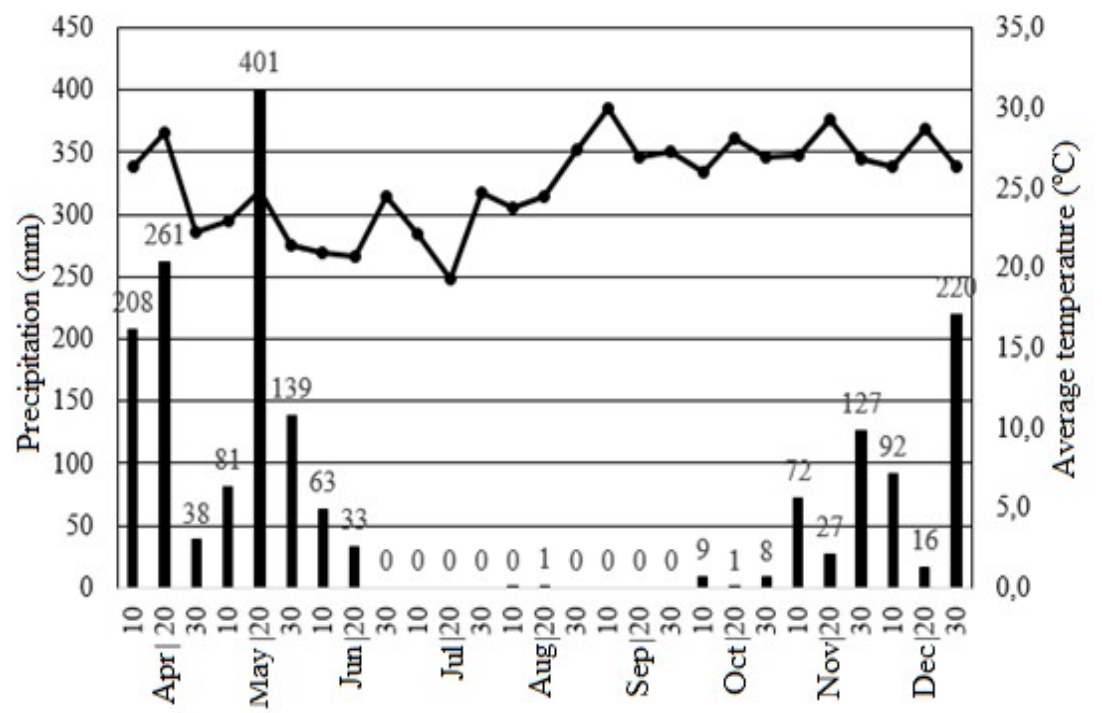

Figure 1. Precipitation and average temperature from April 2017 to December 2017, in Aquidauana-MS.

The experimental design was a randomized block with four treatments and four replications. Green manures evaluated were: Mucuna pruriens, Canavalia ensiformes, Cajanus cajan, Crotalaria juncea. The plots had 16 lines of ten-meters and were constituted by each of the four species of green manure, whose sowing was done manually on April $3,2017$.
When the green manure species were in the full flowering stage in the same field, they were harvested using the manual brushcutter, and the material was properly distributed on the soil. The legumes reached flowering in two distinct periods, the $M$. pruriens and $C$. ensiformes in May and the $C$. juncea and the $C$. cajan in June, and the harvesting was performed in the May 30, 2017 and June 21, 2017. 
Soil macrofauna...

Green manure desiccation was performed after harvesting on October 17, 2017, and the second herbicide application was performed on November 21, 2017, at a rate of $5.0 \mathrm{~L} / \mathrm{ha}$ Glifosato $\AA$. After the fertilizer was harvested, cotton sowing (Gossypium hirsutum) was carried out on 30 November, 2017, in the no-tillage system and mechanically sown. The plots were composed of 16 lines with $10 \mathrm{~m}$ in length. The spacing between rows adopted was $0.5 \mathrm{~m}$, and the density was from three to five plants $\mathrm{m}^{-1}$.

Soil macrofauna that inhabits the interphase between the vegetation cover and the soil surface was captured by Pitfall traps. The traps consisted of plastic containers with a capacity of $500 \mathrm{ml}$ and 12 $\mathrm{cm}$ in diameter, which were buried to ground level, containing water up to $1 / 3$ of their capacity and 10 $\mathrm{mL}$ of detergent to break the surface tension of the water and allowing the insects to be deposited into container bottom. To avoid insect deterioration, it was added $10 \mathrm{~mL}$ of formalin diluted to $4 \%$. The organisms were removed from the traps every seven days and the liquid was renewed. A trap was installed in each experimental unit, the collections were performed weekly until the 60 days after the sowing (DAS) of cotton.

The material was recorded with the treatment date and code and sent to the Unit's entomology laboratory. Macrofauna organisms were screened and clustered by Class or Order, quantified and reported as number of specimens/trap/day, and the traps remained active up to 60 DAS of the cotton crop. Associated with the traps, a soil monolith per legume species was collected at green manure showing, at flowering and 60 DAS. After the demarcation using a $25 \times 25 \mathrm{~cm}$ wooden mold, the plant litter corresponding to the collection area was removed and packed into plastic bags. Subsequently, the area next to the template was excavated and the soil of the sampled area was cut using metal spatulas aiming at removing from 20 to $30 \mathrm{~cm}$ length in layers of 0-10, 10-20, and 20-30 $\mathrm{cm}$, which was packed into plastic bags and subjected to the extraction and classification of animals at the laboratory, where the classification and counting (abundance) of the individuals belonging to each order were performed.

Initially, a cluster analysis of the green manures regarding the soil macrofauna occurrence was performed. Later, a cluster analysis of months regarding the soil macrofauna occurrence was performed. Ward's agglomerative hierarchical algorithm was adopted using Euclidean distance as dissimilarity measure (EVERITT; DUNN, 1991).
SOUZA, E. R. C. et al.

Ward algorithm form clusters minimizing dissimilarity, or minimizing total sums of squares within clusters, also known as the sum of squared deviations (SSD). At each step of the procedure, clusters are formed so that the resulting solution has the lowest SSD within clusters. In these steps, the unions of all possible pairs of groups are considered, and the two resulting in a smaller increase in SSD are clustered until all individuals belong to only one cluster.

To verify the association of macrofauna orders with the months, a canonical analysis was performed. All statistical analyses were performed by using the Rbio software.

\section{RESULTS AND DISCUSSION}

Orthoptera, Coleoptera L (larval), Hymenoptera and Coleoptera (adult) were the most abundant orders with means of $98,88,68$, and 61 individuals per legume species, respectively (Table 2). The high incidence of Hymenoptera and Orthoptera in different cropping systems is associated to its detritus activity: the fragmentation of vegetal material deposited on the soil, as well as related to a certain vegetal cover (SOUZA et.al. 2017). Mendes et. al. (2011) suggest a linkage of these orders with leguminous species, since organisms of these orders prefer dense vegetation cover, justifying the abundance of them owing to the green manure species used.

According to Petillon et al. (2006), the type of soil and vegetation cover, as well as the environmental and regional conditions, are important attributes that determine the composition and richness of the incidence of adult and larval Coleoptera individuals.

C. cajan and C. juncea are the species in which the largest occurrences of soil macrofauna were found, with emphasis on the orders Orthoptera and Coleoptera L. This caused these species to cluster the Group II (Figure 2), while the other species were allocated in Group I. By researching legumes such as $C$. juncea and $C$. cajan, Dias et al. (2007) observed that the presence of these legumes contributed and benefited the increased soil fauna diversity, which shows that plant diversity favors soil macrofauna. Santos et. al. (2008) reported in their study that Coleoptera larvae would be associated with the crotalaria and guandu treatments. These results agree with those found here, where these species alone formed the Group II (Figure 2). 
Table 1. Number of soil macrofauna individuals found in each green manure species, grown from April 2017 to January 2018 in Aquidauana, MS.

\begin{tabular}{lccccc}
\hline Orders & M. pruriens & C. ensiformes & C. juncea & C. cajan & Mean \\
\hline Lepdoptera & 33 & 39 & 30 & 62 & 41 \\
Coleoptera & 45 & 32 & 54 & 112 & 61 \\
Coleoptera L & 78 & 81 & 124 & 69 & 88 \\
Orthoptera & 87 & 72 & 116 & 119 & 98 \\
Diptera & 17 & 22 & 29 & 19 & 22 \\
Blattaria & 12 & 7 & 16 & 29 & 16 \\
Hymenoptera & 41 & 54 & 90 & 89 & 68 \\
Isoptera & 67 & 44 & 22 & 25 & 39 \\
Hemiptera & 28 & 24 & 66 & 52 & 42 \\
Chilophoda & 0 & 1 & 1 & 1 & 1 \\
Diplopoda & 4 & 2 & 2 & 6 & 3 \\
Spider & 35 & 32 & 45 & 42 & 38 \\
Scorpion & 0 & 0 & 1 & 1 & 1 \\
Dhermaptera & 21 & 9 & 28 & 23 & 20 \\
Isopoda & 0 & 2 & 3 & 1 & 2 \\
\hline Total & 468 & 421 & 627 & 650 & \\
\hline
\end{tabular}

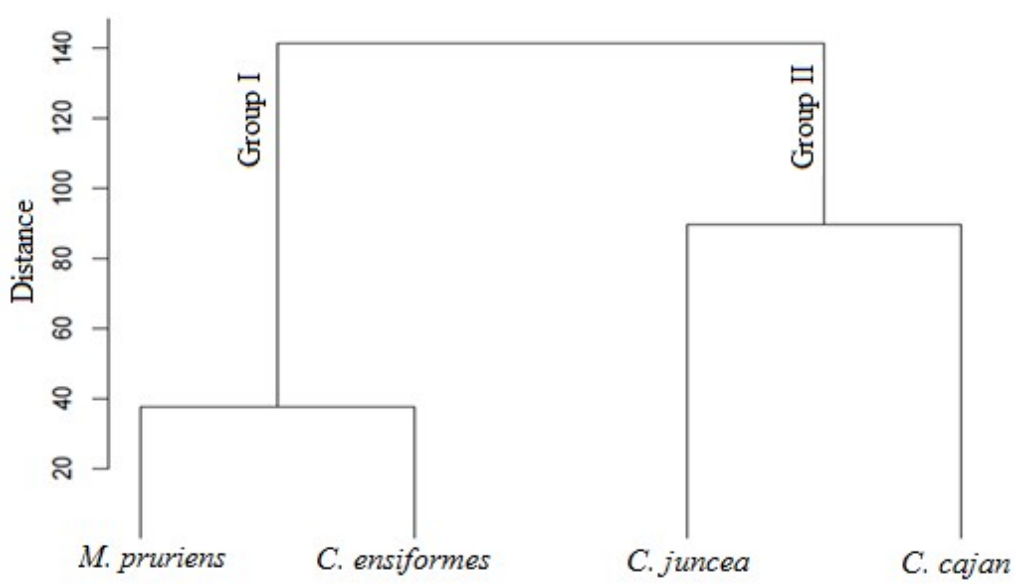

Figure 2. Clustering dendogram among the green manure species based on the number of soil macrofauna individuals.

M. pruriens was the species of highest occurrence for Isoptera individuals, forming the Group I together with $C$. ensiformes. The high relative and population density of Isoptera associated with abundant vegetation cover may be related to the termite's colonial habit regarding the food availability (MENEZES et al., 2009)

Loranger et al. (1998) reported that humidity, temperature and soil type are the factors that most affect the success of establishing termites, which can be bioindicators of habitat change, indicating quantitative changes in the decomposition process (JONES et. al., 2000). Another hypothesis observed by Souza et al. (2017) for the highest occurrence of a fauna in soil covered by a particular plant species is the quality of the food. In this case, the soil covering plant, which will be the food, must be in the form of fresh or decomposed matter, a determining condition in the composition and activity of soil organisms. 
The highest mean for the number of individuals in the soil macrofauna was verified in September (Table 3). This caused this month to be separately allocated into the Group I in cluster analysis (Figure 3). Moreover, this association was identified by the canonical analysis (Figure 5), where the vector of this order is positioned near the month of September.

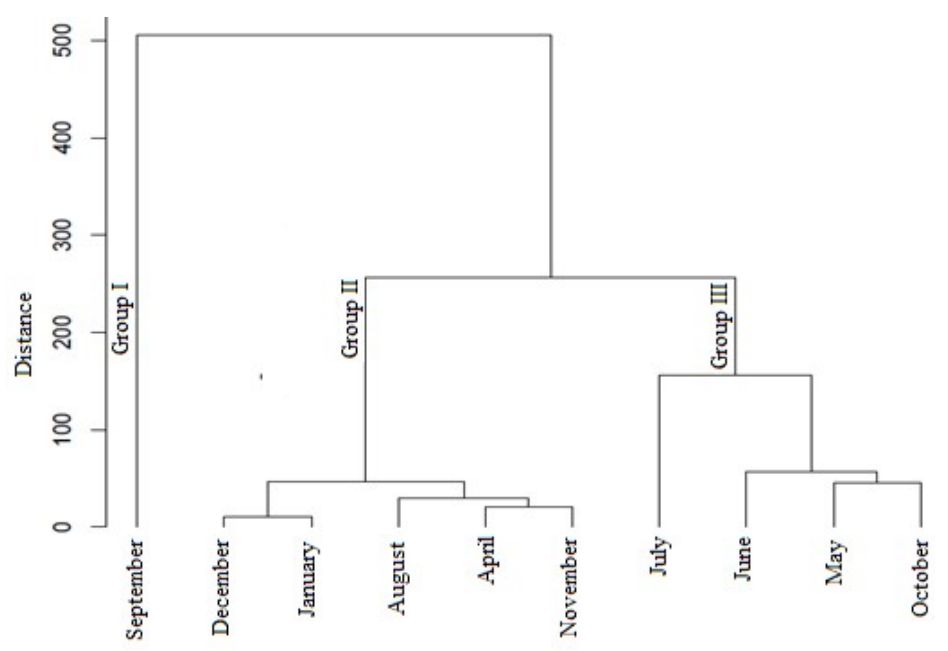

Figure 3. Clustering dendogram between the months of the year based on the number soil macrofauna individuals.

Santos et. al. (2008) also observed a higher density of macrofauna individuals in September in the municipality of Santo Antônio de Goiás, GO. Lavelle (2006) reported that, among other factors, the climate is determinant for the population dynamics of the soil fauna. The conditions of temperature and mulching decomposition stage mulching may have favored the abundance in September (BARETTA et al., 2007). Climatic conditions occurred in the month of September as: absence of rainfall, low relative humidity and high temperatures may justify the greatest abundance verified. Thus, the month of September composed the Group I generated by cluster analysis (Figure 4). After September, the highest means in relation to individuals occurred in May, June, July and October, which formed the Group III.

Tabela 2. Number of soil macrofauna individuals as a function of the in four green manure species in Aquidauana MS.

\begin{tabular}{|c|c|c|c|c|c|c|c|c|c|c|c|c|c|c|c|c|c|}
\hline Months & $\begin{array}{l}\frac{\pi}{0} \\
\frac{0}{0} \\
\frac{0}{0} \\
\frac{0}{0} \\
.\end{array}$ & $\begin{array}{l}\frac{\pi}{0} \\
\frac{0}{0} \\
\frac{0}{0} \\
0\end{array}$ & 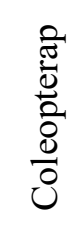 & $\begin{array}{l}\bar{\pi} \\
\frac{\pi}{0} \\
\tilde{0} \\
\frac{0}{0} \\
0\end{array}$ & 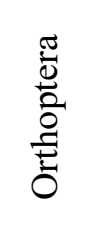 & 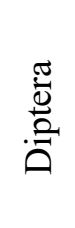 & $\frac{\frac{\pi}{\mathbb{\pi}}}{\frac{\pi}{\pi}}$ & 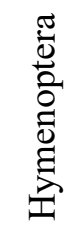 & $\begin{array}{l}\widetilde{0} \\
\stackrel{0}{0} \\
\stackrel{0}{0} \\
0 \\
0\end{array}$ & 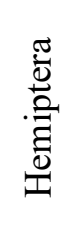 & $\begin{array}{l}\frac{\pi}{0} \\
0 \\
\frac{0}{2} \\
\frac{0}{3} \\
0\end{array}$ & $\begin{array}{l}\frac{\pi}{0} \\
\frac{0}{0} \\
\frac{0}{0} \\
\frac{1}{0}\end{array}$ & $\begin{array}{l}\overline{\bar{\theta}} \\
\overline{\tilde{n}} \\
\text { के }\end{array}$ & 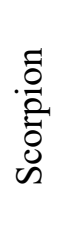 & 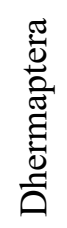 & 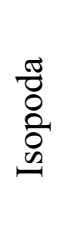 & $\sum_{\text {है }}^{\mathbb{E}}$ \\
\hline April & 11 & 21 & 8 & 0 & 17 & 4 & 2 & 1 & 0 & 5 & 0 & 0 & 4 & 0 & 5 & 0 & 78 \\
\hline May & 22 & 21 & 14 & 6 & 60 & 13 & 9 & 31 & 3 & 5 & 0 & 1 & 15 & 0 & 24 & 0 & 223 \\
\hline June & 38 & 33 & 14 & 1 & 96 & 14 & 9 & 32 & 10 & 23 & 1 & 5 & 20 & 0 & 15 & 0 & 309 \\
\hline July & 56 & 25 & 19 & 7 & 84 & 23 & 5 & 117 & 43 & 66 & 1 & 0 & 39 & 0 & 8 & 3 & 496 \\
\hline August & 2 & 15 & 1 & 26 & 14 & 0 & 1 & 3 & 2 & 6 & 0 & 0 & 4 & 0 & 0 & 0 & 74 \\
\hline September & 3 & 64 & 10 & 305 & 56 & 1 & 13 & 47 & 66 & 27 & 0 & 1 & 35 & 1 & 11 & 1 & 641 \\
\hline October & 22 & 53 & 23 & 6 & 45 & 13 & 10 & 16 & 12 & 21 & 1 & 1 & 24 & 1 & 16 & 1 & 263 \\
\hline November & 0 & 19 & 5 & 6 & 14 & 2 & 4 & 13 & 8 & 9 & 0 & 1 & 9 & 0 & 1 & 1 & 91 \\
\hline December & 0 & 1 & 13 & 0 & 5 & 13 & 0 & 11 & 7 & 5 & 0 & 0 & 4 & 0 & 1 & 0 & 58 \\
\hline January & 0 & 1 & 16 & 0 & 7 & 4 & 1 & 14 & 4 & 7 & 0 & 0 & 4 & 0 & 1 & 0 & 58 \\
\hline Total & 155 & 253 & 121 & 356 & 397 & 87 & 54 & 285 & 154 & 173 & 2 & 9 & 156 & 1 & 82 & 6 & \\
\hline
\end{tabular}


Green manure flowering occurred in May and June, and the desiccation and cotton sowing were carried out in October. In these periods, the plants were not with great vegetal input, which possibly influenced the density of individuals collected. According to Laossi et al. (2008) the density of soil fauna is affected by the quality and quantity of vegetation cover, and the clustering of months possibly occurred as an effect of the vegetation cover decomposition. These authors still found that increased availability of energy and nutrients is associated with habitats favorable to the colonization by these animals (MERLIM, 2005).
SOUZA, E. R. C. et al.

The other months of the year formed the Group II. In November, December and January the soil had the lowest amount of vegetation cover due to desiccation and management for cotton sowing, with the movement of people and machines. In April, due to the green manure sowing, the area did not yet have significant vegetation cover. These factors justify the result obtained, indicating that the soil cover is more determinant than the region climatic conditions, which did not significantly affect the distribution of the soil macrofauna individuals. There was no interaction among vectors and these months according to canonical analysis (Figure 4).

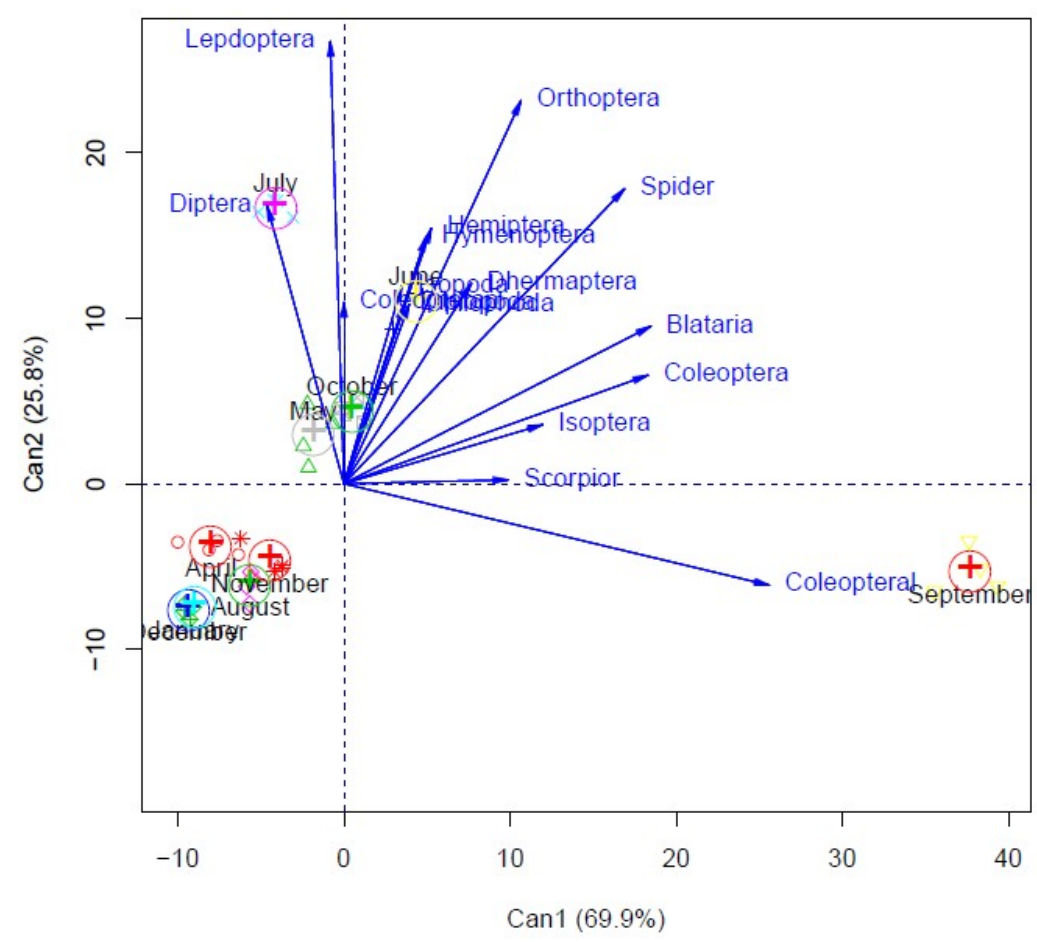

Figure 4. Canonical analysis for the orders of soil macrofauna occurred over the months of April 2017 to January 2018.

Pimentel et al. (2006) found that rainfall and temperature did not have as much influence on the macrofauna as on the type of soil cover, a fact not found in this study for August, when the low rainfall (around $10 \mathrm{~mm}$ ) was the factor that most influenced the macrofauna. However, the results found for August do not agree with the authors mentioned, which may have favored the similarity between these months (December, January, August, April and November), making them compose the Group II.

There was an association among the vectors of Coleoptera L and September (Figure 5), when 305 individuals were collected. Coleoptera larvae act on the decomposition of organic matter and are sensitive to structural variations. The highest number of individuals of this order was possibly due to the humidity and temperature of the environment. According to Silva et al. (2012), the collection periods influence on the abundance variation of soil fauna, as well as the richness and diversity of the groups.

There was an association between the order Diptera and July, occurring more individuals in this month. Some Diptera species are very sensitive to environmental and climatic variations, and for this reason they are used as ecological models and bioindicators (MATA et al. 2010).

Malhães et. al., (2013) states that the humidity and temperature are commonly pointed as determinants in the abundance of the soil fauna, in which the months and seasons of the year can 
present a diversity for the population dynamics of the soil macrofauna. Another hypothesis would be that Diptera has an active role in pollination of flowers (OLIVEIRA et al., 2008), a fact that can justify the association among vector and the month of July, since the flowering of the leguminous species occurred in this period.

In June there was an association with the order Orthoptera, occurring in that month the largest number of individuals, corroborating with results obtained by Souza et. al. (2017), who observed in the same region greater abundance of the order Orthoptera in the mentioned period.

April, November, August and December were the months with the lowest incidence of macrofauna individuals. This alteration may be associated with environmental variables such as average monthly temperature, relative humidity and rainfall, management and anthropogenic actions in the environment, as well as plant and soil characteristics due to the influence of different seasons and vegetation cover (OLIVEIRA-COSTA, 2013).

These factors linked to the lack of a standard methodology make it difficult to compare studies on soil fauna, explaining the need for more research related to soil macrofauna (ARAÚJO; RIBEIRO, 2005).

The density found in soil samples was 70 individuals, considering the periods of green manure sowing and flowering and 60 DAS of the cotton, with orders of greatest abundance being: Coleoptera L, Coleoptera and Oligochaeta, as shown in Table 4.

Table 3. Soil macrofauna individuals as a function of the soil collections in the sowing, flowering and 60 DAS of cotton in four legume species in Aquidauana MS.

\begin{tabular}{|c|c|c|c|c|c|c|c|c|c|c|c|c|c|c|c|}
\hline Species & $\begin{array}{c}\text { Depth } \\
(\mathrm{cm})\end{array}$ & $\begin{array}{l}\frac{\pi}{0} \\
\frac{\pi}{0} \\
\frac{0}{0} \\
.0 \\
0\end{array}$ & $\begin{array}{l}0 \\
\frac{0}{0} \\
\frac{0}{0} \\
\frac{0}{0} \\
0\end{array}$ & $\begin{array}{l}- \\
0 \\
0 \\
000 \\
\frac{0}{0} \\
\frac{0}{0}\end{array}$ & 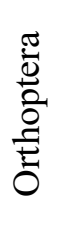 & 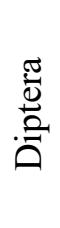 & 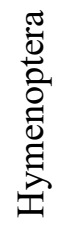 & $\begin{array}{l}\frac{\pi}{0} \\
\stackrel{0}{0} \\
0 \\
0\end{array}$ & 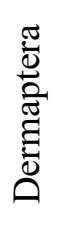 & 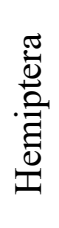 & $\begin{array}{l}\frac{\pi}{0} \\
\frac{0}{2} \\
\frac{0}{0} \\
\frac{\pi}{0}\end{array}$ & $\begin{array}{l}\frac{\pi}{0} \\
\frac{0}{0} \\
\frac{0}{0} \\
\frac{0}{0}\end{array}$ & 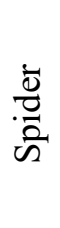 & $\begin{array}{l}\frac{\pi}{0} \\
\frac{0}{0} \\
\frac{0}{0} \\
\frac{0}{0} \\
⿶\end{array}$ & $\stackrel{\pi}{0}$ \\
\hline \multirow{4}{*}{ C. juncea } & Litter & 0 & 1 & 1 & 0 & 0 & 1 & 0 & 0 & 0 & 0 & 0 & 0 & 1 & 4 \\
\hline & $0-10$ & 0 & 5 & 5 & 0 & 0 & 0 & 0 & 0 & 0 & 0 & 0 & 0 & 0 & 10 \\
\hline & $10-20$ & 2 & 0 & 2 & 0 & 0 & 0 & 0 & 0 & 0 & 0 & 0 & 0 & 0 & 4 \\
\hline & $20-30$ & 0 & 0 & 0 & 0 & 0 & 0 & 0 & 0 & 0 & 1 & 0 & 0 & 0 & 1 \\
\hline \multirow{4}{*}{ C. cajan } & Litter & 0 & 0 & 0 & 0 & 0 & 2 & 0 & 0 & 0 & 0 & 0 & 0 & 0 & 2 \\
\hline & $0-10$ & 2 & 6 & 6 & 0 & 0 & 1 & 0 & 0 & 1 & 1 & 0 & 0 & 0 & 17 \\
\hline & $10-20$ & 2 & 0 & 2 & 0 & 0 & 1 & 0 & 0 & 0 & 0 & 0 & 0 & 0 & 5 \\
\hline & $20-30$ & 0 & 0 & 0 & 0 & 0 & 0 & 1 & 0 & 0 & 0 & 0 & 0 & 0 & 1 \\
\hline \multirow{4}{*}{ C. ensiformes } & Litter & 0 & 0 & 1 & 0 & 0 & 0 & 0 & 0 & 0 & 0 & 0 & 0 & 1 & 2 \\
\hline & $0-10$ & 2 & 0 & 1 & 0 & 0 & 1 & 0 & 0 & 0 & 0 & 0 & 0 & 0 & 4 \\
\hline & $10-20$ & 0 & 0 & 5 & 0 & 0 & 0 & 0 & 0 & 0 & 0 & 0 & 0 & 0 & 5 \\
\hline & $20-30$ & 0 & 0 & 1 & 0 & 0 & 1 & 0 & 0 & 0 & 0 & 0 & 0 & 0 & 2 \\
\hline \multirow{4}{*}{ M. pruriens } & Litter & 1 & 0 & 1 & 0 & 0 & 0 & 0 & 0 & 2 & 0 & 0 & 0 & 0 & 4 \\
\hline & $0-10$ & 2 & 0 & 1 & 1 & 0 & 0 & 0 & 1 & 0 & 0 & 0 & 0 & 0 & 5 \\
\hline & $10-20$ & 0 & 0 & 0 & 0 & 0 & 1 & 0 & 1 & 0 & 1 & 0 & 0 & 0 & 3 \\
\hline & $20-30$ & 0 & 0 & 0 & 0 & 0 & 0 & 0 & 0 & 0 & 0 & 1 & 0 & 0 & 1 \\
\hline Total & & 11 & 12 & 26 & 1 & 0 & 8 & 1 & 2 & 3 & 3 & 1 & 0 & 2 & 70 \\
\hline
\end{tabular}

As for the diversity among the soil macrofauna groups, the highest indices were verified at the most superficial layer $(0-10 \mathrm{~cm})$ in the legumes $C$. cajan and $C$. juncea. The influence of the management on the macrofauna is because the greater vegetal cover provided to the soil by the green fertilization, besides the consequent humidity and food supply, led to an increased population of individuals in this layer.

\section{CONCLUSIONS}

The orders Orthoptera, Coleoptera larval, Hymenoptera and Coleoptera adult, respectively, had the highest local relative abundance.

The abundance of soil macrofauna orders ranges according to the green manure and season, where $C$. juncea and $C$. cajan exert a positive influence on the soil macrofauna in the cotton crop at its initial stage. 
RESUMO: Objetivou-se avaliar a abundância da macrofauna do solo em quatro espécies de adubos verdes, antecedendo a cultura do algodão. $\mathrm{O}$ experimento foi instalado na Universidade Estadual de Mato Grosso do Sul - Unidade Experimental de Aquidauana, MS. O delineamento experimental adotado foi em blocos ao acaso com quatro tratamentos: Mucuna pruriens (mucuna cinza), Canavalia ensiformes (feijão de porco), Cajanus cajan (guandu anão) e Crotalaria juncea (crotalária) e quatro repetições. A macrofauna foi capturada por meio de coletas com armadilhas modelo Pitfall. Os dados foram processados mediantes a análise de agrupamento para verificar a similaridade entre as espécies de adubação verde quanto à ocorrência da macrofauna do solo. A maior abundância relativa local foram as ordens, Orthoptera, Coleoptera L (Larva), Hymenoptera e Coleoptera respectivamente. Houve efeito significativo das plantas de cobertura sobre os grupos taxonômicos e densidade relativa da macrofauna edáfica. Os adubos verdes foram mais determinantes na abundância e densidade relativa da macrofauna do solo que o clima da região. Até os 60 dias de implantação da cultura do algodão, houve influência benéfica dos adubos verdes sobre a população da macrofauna do solo.

PALAVRAS-CHAVE: Análise de agrupamento. Densidade de macrofauna. Filo Arthropoda. Gossypium hirsutum. Variáveis canônicas.

\section{REFERENCES}

ALVES, M. V.; SANTOS, J. C. P.; GOIS, D. T.; ALBERTON, J. V.; BARETTA, D. Macrofauna do solo influenciada pelo uso de fertilizantes químicos e dejetos de suínos no oeste do estado de Santa Catarina. Revista Brasileira de Ciência do Solo, v. 32, n. 2. 2008. https://doi.org/10.1590/S0100-06832008000200014

AQUINO, A. M.; SILVA, R. F.; MERCANTE, F. M.; CORREIA, M. E. F.; GUIMARÃES, M. F.; LAVELLE, P. Invertebrate soil macrofauna under different ground cover plants in the no-till system in the Cerrado.

European Journal of Soil Biology, v.44, p.91-97, 2008. https://doi.org/10.1016/j.ejsobi.2007.05.001

ARAÚJO, E. A.; RIBEIRO, G. A. Impactos do fogo sobre a entomofauna do solo em ecossistemas florestais. Natureza e Desenvolvimento, v. 1, n. 1, p.75-85, 2005.

BARETTA, D.; BROWN, G. G.; JAMES, S. W.; CARDOSO, E .J. B. N. Earthworm populations sampled using collection methods in Atlantic Forests with Araucaria angustifolia. Scientia Agrícola, v. 64, p. 384-392, 2007. https://doi.org/10.1590/S0103-90162007000400009

DIAS, P. F.; SOUTO, S. M.; CORRÊIA, M. E. F.; RODRIGUES, K. M.; FRANCO, A. A. Efeito de leguminosas arbóreas sobre a macrofauna do solo em pastagem de Brachiaria brizantha cv. Marandu. Pesquisa Agropecuária Tropical, v.37, p.38-44, 2007.

EVERITT, B.S.; DUNN, G. Applied multivariate analysis. London: Edward Arnold, 1991. 400p.

FREIRE, E. C. F. Algodão no cerrado do Brasil. Brasília: ABRAPA. 2015. 416p.

JONES, D. T.; EGGLETON, P. Sampling termite assemblages in tropical forest: testing a rapid biodiversity assesment protocol. Journal of Applied Ecology, v. 37, p. 191- 203, 2000. https://doi.org/10.1046/j.13652664.2000.00464.x

KLADIVKO, E. J. Tillage systems and soil ecology. Soil and Tillage Research, v. 61, p. 61-76, 2001. https://doi.org/10.1016/S0167-1987(01)00179-9

LAVELLE, P. Assessing the abundance and role of invertebrate communities in tropical soils: aims and methods. Journal of African Zoology, v. 102, p.275-283, 2006.

LAVELLE, P.; SPAIN, A.V. Soil ecology. Dordrecht: Kluwer Academic, 2001. https://doi.org/10.1007/97894-017-5279-4 
LORANGER, G.; PONGE, J. F.; BLANCHART, E.; LAVELLE, P. Influence of agricultural practices on arthropod communities in a vertisol (Martinique). European Journal Soil Biology, v. 34, n. 4, p. 157-165, 1998. https://doi.org/10.1016/S1164-5563(00)86658-3

MATA, R. A, TIDON, R., CORTES L. G., MARCO P., DINIZ, J. A. F. Invasive and flexible: niche shift in the drosophilid Zaprionus indianus (Insecta, Diptera). Biological Invasions, v. 12, p. 1231-1241, 2010. https://doi.org/10.1007/s10530-009-9542-0

MENDES, R.; KRUIJT, M. D. E.; BRUIJN, I.; DEKKERS, E.; VAN DER VOORT, M.; SCHNEIDER, J. H. Deciphering the rhizosphere microbiome for disease-suppressive bacteria, Science, v. 332, p. 1097-1100, 2011. https://doi.org/10.1126/science. 1203980

MERLIM, A. O. Soil macrofauna in cover crops of figs grown under organic management. Scientia Agrícola, v. 62, n. 1, p. 57-61, 2005. https://doi.org/10.1590/S0103-90162005000100011

OLIVEIRA, L. A.; SERRA, A. L. Anatomia comparada do aparelho bucal de espécies pertencentes à Ordem Díptera (Arthropoda, Insecta), com ênfase na morfologia funcional. ConScientia e Saúde, p.83-92, 2008. https://doi.org/10.5585/conssaude.v7i1.1048

OLIVEIRA-COSTA, J.; OLVEIRA, R. G.; BASTOS, C. S. Diptera Calliphoridae de importância forense no município do Rio de Janeiro. Revista Eletrônica Novo Enfoque, v. 16, n. 16, p. 41-52, 2013.

PASINI, A. R., PANIZZI, A. R.; HADDAD, M. L. macrofauna de invertebrados do solo em pastagens no cerrado de Uberlândia-MG. Depto de Agronomia, UEL, Londrina-PR. 1997. Disponível em $<\mathrm{http}$ //horizon.documentation.ird.fr/exldoc/pleins_textes/pleins_textes_6/divers1>. Acesso em $01 \mathrm{Fev} .2018$.

PETILLON, J.; YSNEL, F.; CANARD, A. Spiders as indicators of microhabitat changes after a grass invasion in salt-marshes: synthetic results from a case study in the Mont-Saint Michel Bay. Cahiers de Biologie Marine, v. 47, n. 1, p. 11-18, 2006.

PIMENTEL, M. S.; AQUINO, A. M. de; CORREIA, M. E. F.; COSTA, J. R.; RICCI, M. dos S. F.; DE POLLI, H. Atributos biológicos do solo sob manejo orgânico de cafeeiro, pastagem e floresta em região do médio Paraíba fluminense - RJ, Coffee Science, v. 1, p. 85-93, 2006.

SALTON, J. C.; MIELNICZUK, J.; BAYER, C.; BOENI, M.; CONCEIÇÃO, P. C.; FABRÍCIO, A. C.; MACEDO, M. C. M.; BROCH, D. L. Agregação e estabilidade de agregados do solo em sistemas agropecuários em Mato Grosso do Sul. Revista Brasileira Ciência do Solo, v. 32, p. 11-21, 2008. https://doi.org/10.1590/S0100-06832008000100002

SANTOS, G. G.; SILVEIRA, P. M.; MARCHÃO, R. L.; BECQUER, T.; BALBINO, L. C. Macrofauna edáfica associada a plantas de cobertura em plantio direto em um Latossolo Vermelho do Cerrado. Pesquisa agropecuária brasileira, Brasília, v. 43, n. 1, p. 115-122, jan. 2008. https://doi.org/10.1590/S0100204X2008000100015

SILVA, C. F.; PEREIRA, M. G.; CORREIA, M. E. F.; SILVA, E. M. R. Fauna edáfica em áreas de agricultura tradicional no entorno do Parque Estadual da Serra do Mar em Ubatuba (SP). Revista Ciência Agrária, n. 52, p. 107-115, 2012.

SOUZA, E, R, C.; ABOT, A. R.; RIBEIRO, L.P.; TORRES, F. E.; TEODORO, P. E.; Influência de adubos verdes sobre a macrofauna epiedáfica no Ecótono cerrado/pantanal. Bioscience Journal, v. 33, n. 6, p. 15561561, 2017. https://doi.org/10.14393/BJ-v33n6a2017-37422 